\title{
THE DATA ANALYSIS APPROACH IN IT-SUPPORT OF INCLUSIVE EDUCATION
}

\author{
Volodymyr Pasichnyk \\ Lviv Polytechnic National University, Information Systems and Network \\ Department, Lviv, Ukraine
}

\section{Tetiana Shestakevych}

Lviv Polytechnic National University, Information Systems and Network

Department, Lviv, Ukraine

\section{CMESTE}

JEL Category: 129

\begin{abstract}
The paper considers the features of the modern understanding of education as a learner-centered process. The individualization of the learning takes into account the psycho-physical development of the person, its abilities, and special educational requirements in order to ensure favorable conditions for the full development of the personality. The features of the use of information and communication tools to support inclusive education as a form of learner-centered learning were analyzed. The main requirements for recommender systems of information technology support of learner-centered education were outlined, and the main participants in this process were identified. The recommender system of learner-centered inclusive education gives the opportunity to facilitate the work of participants in this process and make improvements in such a process. The application of information technologies to support learner-centered inclusive education gives the opportunity to accumulate large amounts of data. The use of the multivariate analysis technology for the data processing will allow the most effective planning of educational strategies for persons with special needs.
\end{abstract}

Keywords: education systems, inclusive education, individual learning trajectory, big data, multivariate data analysis

\section{INTRODUCTION}

The modern world is characterized by an active formation of learner-centered learning as a new paradigm of education. Originally, the need of educational services, when the learning process is focused on a student, his abilities, and predisposition, comes from researchers cooperating with children who had specialties of psychophysical development. Modern scholars

Address of the corresponding author:

Tetiana Shestakevych

Tetiana.V.Shestakevych@lpnu.ua believe that the inclusive education (IE) is the most successful way of socialization of person with special needs. Such education offers to the person with special needs an education in a regular class of public school at the place of person's residence.

To improve the support of inclusive education, as well as the access to educational services to persons with special needs it is efficient to use the latest information technologies. The specifics of the maintenance of such education is related directly to the analysis of large amounts of data. 
2 THE ANALYSIS OF THE RECENT RESEARCH PUBLICATIONS

The implementation of the inclusive education requires the customization of the learning process, and such requirement is a characteristic of modern approaches to the implementation of the common learning process (Rushkevych, 2014). Achievements of the researchers of inclusive education have received a new use thanks to a modern understanding of education as a continuous process of improvement, that lasts throughout life (The European Higher Education Area in 2015: Bologna Process Implementation Report, 2015). Thus, an important direction of development of inclusive education coincides with the dominant modern European and world educational trends. An educational process, in which the choice of methods, techniques, the pace of learning considers the individual peculiarities of a person, is called an individualization of learning. Such type of learning pays attention to the level of person's development and ability to learn, no matter what features and to what extent these abilities were developed (Spirina, 2014), (Unt, 1990).

The formation of the person-oriented route of inclusive education for persons with special needs requires the consideration of both the characteristics of its mental and physical development, as well as available specialized tools and problem-oriented resources, that are to support such education. The set of specialized software, technical, informational, and problemsolving resources, that support person-oriented inclusive education is called an information and communication tools (ICT) of inclusive education.

It is purposeful to use modern information technologies to support learner-centered education, and it is crucial accompany the process of inclusive education with new intelligent educational technologies to ensure the stages of such process comprehensively. The appropriate information technologies are developed due to domestic standards of health care and education, pedagogical and psychological technologies, legislative support of inclusive education, etc. Complex support of inclusive education with information technologies allows systematical accumulation of large amounts of data. Such data concern features of the psychophysical development of a person, specialties of one's needs and capabilities. The technology of the multivariate data analysis - the OLAP systems is a convenient tool in big data processing and exploration. Such technology appeared to be useful in decision-supporting (Lytvyn, 2013), knowledge extraction (Nikolskyy, 2008) and the like. The OLAP technology in (Gudkov, 2008) is considered as an easy and fast mean of access, visibility, and operational analysis of educational data. In the (Nazaruk, 2014), the authors suggested multivariate data analysis as a tool to study activities in secondary schools.

\section{OBJECTIVES}

The aim of this study is to analyze the requirements - functional and structural - to the information technology of inclusive education. To ensure the comprehensive multivariate data analysis of the process of inclusive education, the OLAP technology will be explored.

\section{THE MAIN RESULTS OF THE RESEARCH}

The individual educational plan is a part of an individual educational route of inclusive education. The document, that contains the individual educational plans includes learning content and the correction component, both provided by the selected inclusive institution. This plan is based on the desired material and technical, personnel, scientific and methodological support, etc.

The individual educational route for a person with special needs is developed with the participation of educational institutions (preschool, school, universities, etc.), institutions of extra educational activity (art, sport, crafts), places of work, training courses and the like.

In works (Skidmore, 2014) (Vrasmas, 2012) (Watkins, 2006), authors introduce a kind of individual educational plan - a concept of the individual transition plan, which is advisable, in their opinion, to be applied to resolve the transition of persons from one learning plan to another. Such individual transition plans can be useful, for example, in the case of transition from the school to the university, or getting a job, or changing job profile. Transition plan, in particular, makes it possible to increase the chances of a person with 
special needs to pursue higher education and (or) the ongoing work, to combine the interests, desires, motivation, experience, skills and capabilities to the requirements of the university or the profession, working environment, increase the autonomy of such person and confidence in own capabilities. The individual transition plans (ITP) are designed to harmonize and smooth the person transition between educational institutions (from school to university, from university to the place of permanent employment, etc.). The accumulated learning results and their analyses they form the individual educational trajectory of the person.

Let us set the trajectory of inclusive education as a consolidated result of training, correctional and developmental influence on a person in the course of inclusive education, as well as the conclusions of a comprehensive study of these results. This trajectory, being an information trace of inclusive learning outcomes, reflects the educational, social, societal, and creative achievements of a person.

The information and technological support of learner-centered inclusive education is advisable to realize in the form of an appropriate recommender system. Such recommended inclusive education system is an intelligent information system that provides formation of recommendations, concerning the objectives, methods, and means of realization of personoriented training of persons with special needs. Such concern is based on the analysis of the peculiarities of one's psychological development, and corresponding educational trajectory.

The aim of the development of the recommender systems of person-oriented inclusive education is to reduce the information burden on teachers, parents, a person with special needs etc. Such systems use the search - an intelligent selection of the most relevant objects (pedagogical and teaching methodology, ICT tools for inclusive learning, control, etc.) in large data sets. Developed information and communication tools of inclusive learning should combine the design versatility, availability, and regularity of services (Demchuk, 2013), (Lu, 2015), (Rice, 2011), (Wald, 2007). Modern online media, as one of the elements of information and communication tools, enables professionals, parents, and persons with special needs to provide information technology support and maintenance of certain stages of inclusive education (Hodych, 2011), (Ding, 2015), (Pereira, 2011).

The functioning of the recommender systems of person-oriented inclusive education lies in the analysis of the characteristics of the inclusive person, his mental and physical development and individual learning trajectory. Such analysis causes the building of a quality individual educational route, that would meet the principles of learner-centered learning, and ensure the efficient achievement of learning objectives. Modern recommender systems aim to support the user with information and communication in choosing education course, subjects of study and teaching materials, lectures and online discussions, etc. (Boyarinov, 2004).

\subsection{The analysis of requirements of inclusive education participants}

The implication of information technologies to the process of inclusive education will give an effective tool of support such education to those, who are involved in it. The design of such information technologies depends on the necessities of its users. The set of appropriate demands can be described as a use cases diagrams in UML notation (Fig. 1). This gave an opportunity to reveal users of such IT among the participants of inclusive education. Table 1 contains the main groups of such IT system users and the purposes of the groups' system appliance.

Table 1. IE and IT: users and system appliance

\begin{tabular}{|c|l|}
\hline Participants of IE & System appliance \\
\hline $\begin{array}{c}\text { Person with } \\
\text { educational } \\
\text { needs (EN) }\end{array}$ & $\begin{array}{l}\text { to identify the features of } \\
\text { psychophysical development }\end{array}$ \\
\hline $\begin{array}{c}\text { Person with } \\
\text { special } \\
\text { educational } \\
\text { needs (SEN) }\end{array}$ & $\begin{array}{l}\text { to update the individual data; } \\
\text { to the educational trajectory, reporting on an } \\
\text { educational route }\end{array}$ \\
\hline $\begin{array}{c}\text { Specialists of } \\
\text { PMPC }\end{array}$ & $\begin{array}{l}\text { for accumulating data of the } \\
\text { psycho-physical diagnostics. }\end{array}$ \\
\hline $\begin{array}{c}\text { Inclusive } \\
\text { learning } \\
\text { specialists }\end{array}$ & $\begin{array}{l}\text { to evaluate individual } \\
\text { observation; to record } \\
\text { correctional development; }\end{array}$ \\
\hline
\end{tabular}




\begin{tabular}{|c|l|}
\hline Participants of IE & System appliance \\
\hline $\begin{array}{c}\text { Teachers of } \\
\text { public schools } \\
\text { and assistants }\end{array}$ & $\begin{array}{l}\text { development of an individual } \\
\text { education plan; to form } \\
\text { individual transition plans. }\end{array}$ \\
\hline $\begin{array}{c}\text { Employers, } \\
\text { specialists of } \\
\text { employment } \\
\text { centers }\end{array}$ & $\begin{array}{l}\text { for the analysis of the } \\
\text { educational trajectory of a } \\
\text { person through generated } \\
\text { reports. }\end{array}$ \\
\hline
\end{tabular}

Among other things, the system makes the estimates obtained from doctors and psychologists of public profile, analyzes the accumulated data (in particular, with the purpose of identifying special needs), is monitoring the psychological and medical aspects of socialization while inclusive education.

The information technology of the learnercentered learning support, which would take into account individual peculiarities of psychophysical development of the pupils and give the opportunity to satisfy their educational needs in the course of formation of individual educational plans, must satisfy the following requirements (Vagramenko, 2005), (Kravets, 2003):

- To create conditions for the selection of learning content in accordance with the educational opportunities and needs of a person and the level of acquired competencies,

- To provide at the same time training and corrective work with a person according to the peculiarities of his mental and physical development,

- build individual educational plan taking into account the achieved level of acquisition of competencies and level of psychophysical development,

- ensure optimal selection of the educational content on relevant topics,

- contribute to the synthesis of contemporary pedagogical, correctional and information technologies,

- to ensure the formation of individual learning trajectory of the person, supporting the accumulation of learning outcomes and to their analysis.

Additional benefits of applying the information technology support of learner-centered inclusive education will be the opportunity to increase the efficiency of the educational process, to adapt quickly to changing conditions, to optimize the channels of gathering information, to automate control of learning outcomes; to analyze learning outcomes; to automate and improve the planning of the educational process.

\subsection{The features of multivariate data analysis of inclusive education}

The participants of the inclusive education can be classified as those who work with the system of IT support, and those, who can be a source of data to the system. Let us denote by $K$ the set of roles of persons, who are a to be sources of data in inclusive education process:

$$
K=\left\{K_{1}, K_{2}, \ldots, K_{12}\right\} .
$$

Here $K_{1}$ stands for the person with educational needs, $K_{2}$ - the person with special educational needs, $K_{3}$ - the physicians of the PMPC, $K_{4}$ - other physicians, whom the person was consulting with, $K_{5}$ - the physicians, affiliated with the inclusive educational institution, $K_{6}$ - the psychologists of the PMPC, $K_{7}$ - other psychologist, whom the person was consulting with, $K_{8}-$ the psychologists, affiliated to the inclusive educational institution $K_{9}$ - the educators of the PMPC, $K_{10}$ - the educators, affiliated to the inclusive educational institution, $K_{11}$ - the educators, affiliated to the institutions of additional education (sport, art workshops etc.), $K_{12}-$ parents. Table 1 shows the interrelation between the participants of the inclusive education - as a data sources, and the information technologies of such educational process, which are to support it (in Table 2, the letter S stands for the source of the data). Understanding the features of the data accumulation in inclusive educations allows designing functional requirements to the corresponding complex of information technologies in the context of data storage.

For example, the accumulation of data, received from the person with special needs, mostly takes place at all stages of such process. First, the data inclusive education is collected at the stage of person diagnosing with help of psychological, medical and pedagogical services (psychological, medical, and pedagogical consultation - PMPC). Second, such data accumulates at the stage of compiling academic and corrective outcomes. The set of such data - both text or speech - is called 
the corpus of inclusive education texts. Creating a inclusive education, as well as in learner-centered facility to analyze such texts is a relevant task in education.

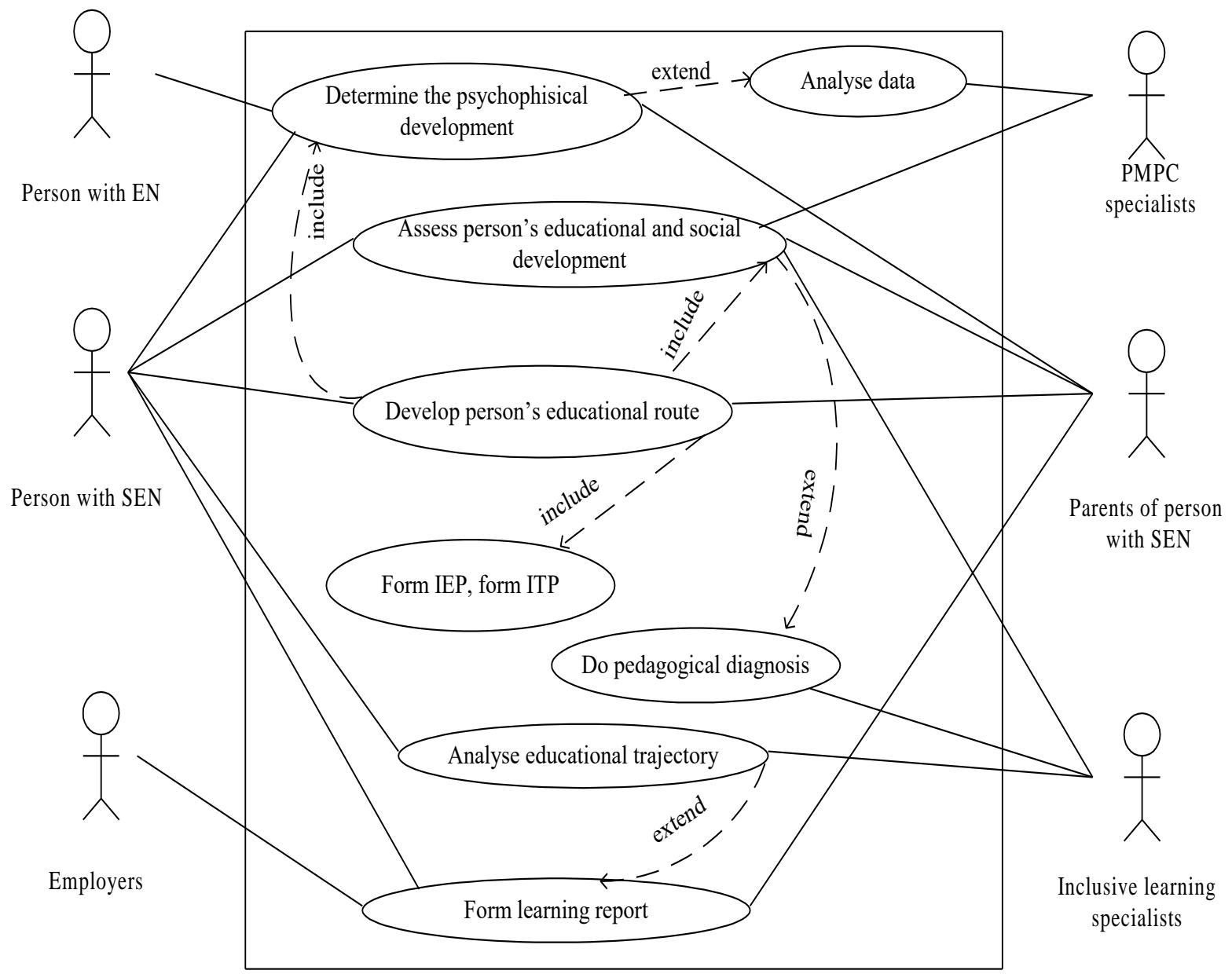

Fig. 1 Use of the case diagram of personally-oriented inclusive education IT support

The need for storage of big inclusive education data requires the application of information technologies. Such technologies should enable the storage and processing of big data amounts for further analysis. The modern means of such data accumulation and processing is data warehouse technology, a significant component of which is a complex multi-dimensional data analysis - OLAP. The use of OLAP technology to processing data, that were accumulated in the process of inclusive education, will give the opportunity to analyze the social development of the person with special needs, one's academic and correctional progress etc.

The multivariate approach is based on the idea of certain calculations on inclusive education data, conducted often or time-consuming, and saving those results for the later use. Saved results can be used in the process of knowledge extraction and decision-making. Basic concepts of the multidimensional data models are data hypercube, dimension, attribute, cell, relation (Shakhovska, 2009).

The hypercube of inclusive education data will be specified as a set of cells, which define the set $V$ and $A$ : $H_{I E}(V, A)$, where: $V$ is a set of hypercube dimensions, $A_{V_{i}}=\left\{A_{1_{i}}, A_{2_{i}}, \ldots, A_{k_{i}}\right\}, i=1, \ldots, n$ is a set of the dimension attributes $V_{i}$, $\left.A=A_{V_{i}} \cup A_{V_{i}} \cup \ldots \cup A_{V_{n}}\right\}$ is a set of the hypercube attributes, $V^{\prime} \subseteq V$ is a set of fixed dimensions, $A^{\prime} \subseteq A$ is a set of fixed attributes. The notation $H_{I E}^{\prime}\left(V^{\prime}, A^{\prime}\right)$ describes a subset of the hypercube data, that corresponds to a set of fixed values. A set of cells, that corresponds to the desired attributes and dimensions, we shall denote $H_{I E}^{\prime}\left(V^{\prime}, A^{\prime}\right) \mid H_{I E}^{\prime} \subseteq H_{I E}$. 
Table 2. Information technology of data sources in inclusive education

\begin{tabular}{|c|c|c|c|c|}
\hline \multirow[b]{2}{*}{$\begin{array}{l}\text { Inclusive } \\
\text { process } \\
\text { participants }\end{array}$} & \multicolumn{4}{|c|}{ Information technology } \\
\hline & 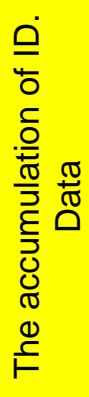 & 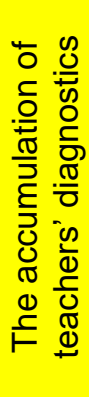 & 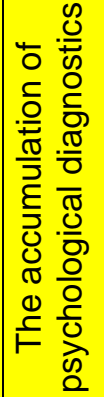 & 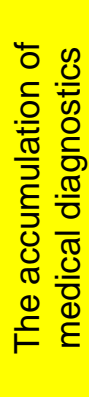 \\
\hline$K_{1}$ & $S$ & $S$ & $S$ & $S$ \\
\hline$K_{2}$ & $S$ & $S$ & $\mathrm{~S}$ & $\mathrm{~S}$ \\
\hline$K_{3}$ & & & & S \\
\hline$K_{4}$ & & & & $\mathrm{~S}$ \\
\hline$K_{5}$ & & & & $S$ \\
\hline$K_{6}$ & & & $S$ & \\
\hline$K_{7}$ & & & $S$ & \\
\hline$K_{8}$ & & & $S$ & \\
\hline$K_{9}$ & & $S$ & & \\
\hline$K_{10}$ & & $S$ & & \\
\hline$K_{11}$ & & $S$ & & \\
\hline$K_{12}$ & $S$ & & $S$ & $S$ \\
\hline
\end{tabular}

The process of inclusive education was research from the point of view of data accumulation. As a result, key dimensions of the multidimensional data model of this process were determined (Shestakevych \& Pasichnyk, 2015). Each dimension consists of several consecutive levels, which, in turn, are parameters of other relations between dimensions. The multi-dimensional nature of OLAP data cube construction is presented in Fig. 3 (Ovsianitskaya, 2014). An example of such a hierarchical dimension is disease classification: Disorder - Speech Disorder - Type of Speech Disorder (Apraxia of speech Cluttering, Dysprosody, Muteness etc.).

The procedure of information obtaining from the data hypercube is in the operation of the dice with the corresponding dimension values, i.e. $H_{I E}^{\prime} \subseteq$ $H_{I E}$. For example, an information about psychologists' work with a person with precise speech disorder can be obtained. To do this, the data cube should be diced by dimension "Psychologist Affiliation", "Speech Disorder", and "Date". A point in this space will describe the ID of a person with a speech disorder, treated by the specialist.

Figure 2 shows another possible choice of the cube dimensions, based on person-oriented inclusive education data. Data cube allows conducting a detailed analysis of the characteristics of inclusive educational process separately by years of study, inclusive schools and characteristics of educational activities. If necessary, you can conduct a further detail for each of the aggregated dimensions - years of study, inclusive schools or characteristics of educational activity.

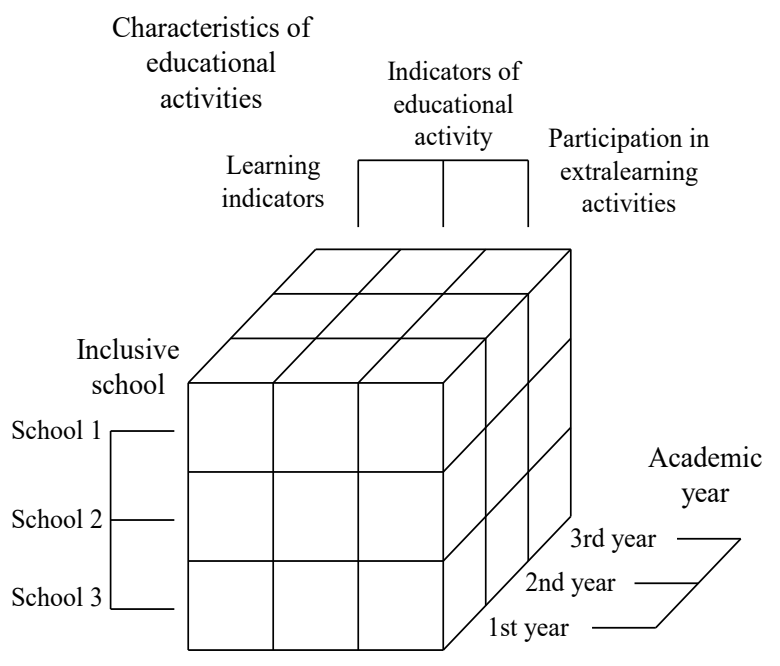

Fig. 2. Data cube dimensions

The dice operation in formed data cube (Fig. 2) allows solving the following analytical tasks for further data analysis:

- research about educational activity characteristics - with fixed measurements "Inclusive school" and "Academic year";

- research about the level of an extra educational involvement of inclusive schooling (with fixed measure "Participation in extra learning activities" and the summation on the "Academic year" dimension) - to analyze the influence of an additional education on academic results.

Figure 3 shows the cube of the second level of the hierarchy. This inclusive education data cube provides the opportunity to conduct an analysis of the educational characteristics. As such can be mentioned the correctional activities, the indicators of such activities, the inclusive classes or the academic semesters. 


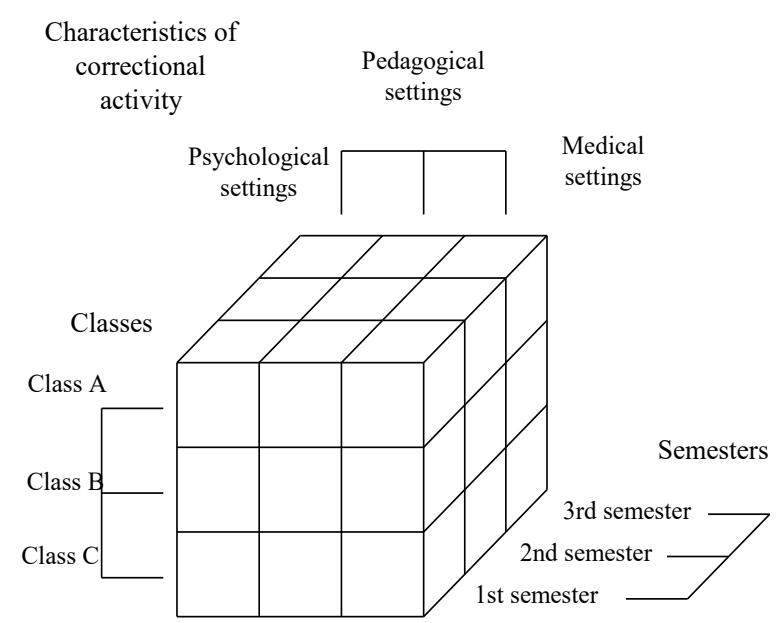

Fig. 3. The second level of the data cube

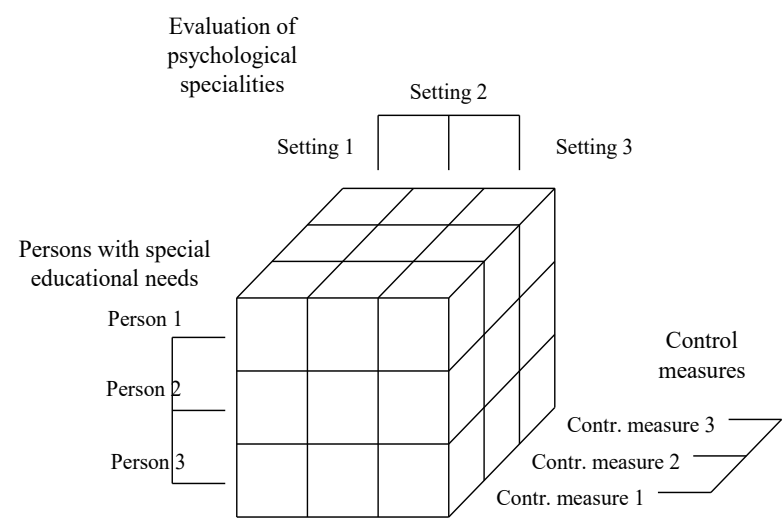

Fig. 4. The third level of the data cube

The dice operation in data cube at Fig. 3 allows solving, among others, the analytical tasks of operating with data in order to perform a research about the level of an extra educational involvement of inclusive schooling. To do so, the measure "Participation in extra learning activities" is to be fixed, and the summation of the "Semester" dimension performed - to analyze the influence of psychological characteristics of the correction measures in different inclusive classes. Cube of the third level of the hierarchy is presented in Fig. 4. Such inclusive education data cube provides an opportunity to analyze the evaluation of psychological characteristics of a person per certain psychological parameters, results of control measures or persons.

\section{CONCLUSIONS}

The learner-centered education, that considers personal characteristics of students, as well as ensures the full development of the individual cognitive abilities, is an innovative form of the learning process. Having exceptionally high value, such education for persons with special needs allows encouraging students to educational activity, providing conditions for a full social inclusion. The application of modern IT technologies became a relevant task - both scientific and practical.

In this paper, the authors considered the possibility of applying the multivariate data analysis techniques for a comprehensive operational analysis of data (including a corpus of inclusive education texts). The ability to organize and present the data in terms of various analytical tasks demonstrates the feasibility of an OLAP system. Such technology is an effective tool in IT support of learner-centered inclusive education.

\section{WORKS CITED}

Boyarinov, D. (2004). Designing learner-centered learning system. Smolensk.

Demchuk, A. B. (2013). Educational video for people with visual impairments. The work and experience of the National University "Lviv Polytechnic". Kyiv. Lviv.

Ding, C. A. (2015). Web-based multi-linguists symbol-to-text AAC application. Florence.

Gudkov, A. A. (2008). The system of decision-making support on the basis of KDD technologies in educational management. University education: XIIth International scientific-method. conference, 297-299.

Hodych, O. D. (2011). Computer gesture recognition: software-algorithmic approach. Lviv.

Kravets, R. B. (2003). The organization of multidimensional presentation and information analysis in relational databases. Information Systems and Networks, 178-193.

Lu, J. W. (2015). Recommender system application developments: A survey. Decision Support Systems, 12-32. 
Lytvyn, V. (2013). The process of supporting managerial decision-making in early warning. Actual Problems of Economics, pp. 222-229.

Nazaruk, M. V. (2014). Information technology of activities analysis in secondary schools. Information Systems and Networks, Bulletin of Lviv Polytechnic National University, 458-466.

Nikolskyy, Y. V. (2008). Intelligent analysis of psychological testing results. Information Systems and Networks, Bulletin of Lviv Polytechnic National University, 113-137.

Ovsianitskaya, L. Y. (2014). Application of OLAP-cubes for data analysis of pedagogical monitoring. Herzen A. I. Russian state pedagogical university Bulletin, 271-279.

Pereira, F. A.-d.-S. (2011). MOLinsight: A Web Portal for the Processing of Molecular Structures by Blind Students. Chemistry Education, 361-362.

Rice, D. (2011). Use of ICTs for Inclusive Education: costs and benefits. Benefits and costs of eaccessibility. Paris.

Rushkevych, Y. M. (2014). The Bologna process and the new paradigm of higher education. Lviv: Lviv Polytechnic Publishing House.

Shakhovska, N. B. (2009). Warehouses and data space. Lviv: NU "Lviv Polytechnic".

Shestakevych, T., \& Pasichnyk, V. (2015). The application of multivariate data analysis techniques to support inclusive education. Scientific and Technical Conference" Computer Sciences and Information Technologies"(CSIT), 2015 Xth International, (pp. 88-90). Lviv.

Skidmore, K. W. (2014). Assessment to Guide Individualized Transition Plans from School to PostSchool for Children Ages 14+ with Moderate Disabilities.

Spirina, T. F. (2014). Zarubezhnyi i otechestvennyi opyt individualizatsii obucheniia $v$ vysshei shkole. Mir nauki, kul'tury, obrazovaniia [Foreign and native individualization learning experience in higher education]. The world of science, culture, education, 110-113.

(2015). The European Higher Education Area in 2015: Bologna Process Implementation Report. Luxembourg.

Unt, I. (1990). Individualization and differentiation of learning. Moscow: Pedagogics.

Vagramenko, Y. A. (2005). Technical and technological requirements for adaptive automated information system of educational process management in comprehensive school. Academy of Informatization of Education, 3-19.

Vrasmas, E. a. (2012). Transition from school to work at young people with disabilities. Procedia- Social and Behavioral Sciences, pp. 433-437.

Wald, M. (2007). A Research Agenda for Transforming Pedagogy and Enhancing Inclusive Learning through Synchronised Multimedia Captioned Using Speech Recognition. World Conference on Educational Multimedia, Hypermedia \& Telecommunications, (pp. 4479-4484).

Watkins, A. (2006). Individual transition plans: supporting the move from school to employment. (p. 44). Middelfart: European Agency for Development in Special Needs Education.

This work is an extension and continuation of (Shestakevych \& Pasichnyk, 2015)

Received for publication: 07.11.2016

Revision received: $\quad 20.01 .2017$

Accepted for publication: 24.01.2017 


\section{How to cite this article?}

Style - APA Sixth Edition:

Pasichnyk, V., \& Shestakevych, T. (2017, July 15). The data analysis approach in IT-support of inclusive education. (Z. Čekerevac, Ed.) MEST Journal, 5(2), 102-110. doi:10.12709/mest.05.05.02.11

Style - Chicago Sixteenth Edition:

Pasichnyk, Volodymyr, and Tetiana Shestakevych. "The data analysis approach in IT-support of inclusive education." Edited by Zoran Čekerevac. MEST Journal (MESTE) 5, no. 2 (July 2017): $102-110$

Style - GOST Name Sort:

Pasichnyk Volodymyr and Shestakevych Tetiana The data analysis approach in IT-support of inclusive education [Journal] // MEST Journal / ed. Čekerevac Zoran. - Toronto - Belgrade : MESTE, July 15, 2017. - 2 : Vol. 5. - pp. 102-110.

Style - Harvard Anglia:

Pasichnyk, V. \& Shestakevych, T., 2017. The data analysis approach in IT-support of inclusive education. MEST Journal, 15 July, 5(2), pp. 102-110.

Style - ISO 690 Numerical Reference:

The data analysis approach in IT-support of inclusive education. Pasichnyk, Volodymyr and Shestakevych, Tetiana. [ed.] Zoran Čekerevac. 2, Toronto - Belgrade : MESTE, July 15, 2017, MEST Journal, Vol. 5, pp. 102-110. 